\section{Doctor as Environmental Steward}

\section{To the Editor:}

In our society the doctor plays many roles: healer, community leader, scientist, advocate for patients, confidante, and role model. Another vital role for today's physician is as environmental steward. The health of human beings relies on the health of our planet, and doctors can do more to protect both. Doctors need to begin fighting for global environmental issues. On a local level, the doctor is in a unique position to affect change. Furthermore, doctors can be healthier people and role models themselves when they are more personally connected to the environment around them.

As science propels forward at breakneck speed, scientists are becoming better at discovering and describing just how sick our planet is. From global warming to water pollution to smog, the Earth is in trouble. With a sick planet come sick inhabitants. It is estimated that 1.8 million people die each year from diarrheal diseases, with a majority of these cases attributed to unsafe drinking water. ${ }^{1}$ In February 2008, chemicals leaking into the Dongjing River in central China turned the water red and foamy, cutting the water supply to over 100000 people. ${ }^{2}$ In Australia, as the ozone layer becomes more depleted, there has been a $41 \%$ increase in melanoma since 1993. ${ }^{3,4}$ Our cities are dirty and smog-filled, as an estimated one fourth of the world's population lives exposed to unhealthy concentrations of air pollutants. ${ }^{5}$ As doctors, it is our duty to point out the connections between the health of the Earth and the health of the human race. We must perform the studies, raise the issues before government officials, start campaigns, strike up public awareness, and facilitate change.

Perhaps a more direct and practical way for many doctors to become stewards for the environment is by working on a local level. As more and more adolescents grow up obese, with their only interactions with the wilderness occurring through video games and movies, it is time for doctors to stand up and shout, "Get out and see the mountains!" Put trail maps and magazines like National Geographic next to the People Magazine in the waiting room. Start wilderness interest groups and recycling programs at the hospital. Advocate for city-wide recycling programs. While these activities may be unrelated to the daily practice of medicine, as a doctor your voice goes far. Question the quality of your town's water and air and fight to improve access to safe parks. These quality improvement checks are the doctor's responsibility-if doctors don't take on these challenges, environmental problems with real solutions may slip through the cracks. When patients begin to take advantage of a healthier local environment, they become healthier patients.

As Paul Auerbach suggests, the field of medicine can become more connected with environmental issues by incorporating them into the medical school curriculum. ${ }^{6}$ My own recent experience as a student on a wilderness medicine rotation has impacted the way I want to live my life personally as a doctor. I want to live a healthy life and help others to do the same. I plan to trade treadmill for trail, to enjoy and participate in nature. When doctors have a personal connection with the environment, advocacy for environmental issues becomes more important. As role models, doctors can then share stories and thoughts about their relationships with the wilderness and inspire others to explore. Take a trip into the woods during your vacation. Explore the wild world while it still exists, and bring a friend with you who has not experienced the wonderful world away from roads and billboards and smokestacks.

Doctors are healers, and the Earth is a patient worth saving. On a global, local, and personal level, let us use our positions of influence to make a difference. Let doctors first do no harm and, second, try to help steward our planet to health.

Daniel Shumer, MD

Burlington, VT, USA

\section{References}

1. World Health Organization. Water, sanitation and hygiene links to health. Available at: http://www.who.int/watersanitation_health/publicatinos/facts2004/en/index.html. Accessed July 21, 2008.

2. International Herald Tribune. Pollution turns river red in central China. Available at: http://www.iht.com/articles/ 2008/02/27/asia/china.php. Accessed July 21, 2008.

3. De Gruijl FR. Skin cancer and solar UV radiation. Eur J Cancer. 1999;35:2003-2009.

4. Australian Government, Department of Health and Ageing. National Skin Cancer Awareness Campaign. Fact sheets. Key statistics. Available at: http://www.skincancer.gov.au/ internet/skincancer/publishing.nsf/Content/fact-2. Accessed July $21,2008$.

5. World Health Organization. Air pollution. Available at: http://www.who.int/ceh/risks/cehair/en/. Accessed July 21, 2008.

6. Auerbach PS. Physicians and the environment. JAMA. 2008;299:956-958. 